\title{
A MORPHOMETRIC STUDY OF THE PROXIMAL END OF DRY ADULT FEMORA
}

Ishita Sengupta (Ghosh) ${ }^{1}$, Madhumita Mahato ${ }^{2}$, Gairik Sengupta *3, Jadab Chandra Chattopadhyay ${ }^{4}$.

${ }^{1}$ Assistant Professor, Dept of Anatomy, Medical College, Kolkata, India.

${ }^{2}$ Senior Resident, Dept of Anatomy, Purulia Government Medical College \& Hospital, Kolkata, India.

${ }^{* 3}$ Associate Professor, Dept of Pharmacology, Institute of Post Graduate Medical Education \& Research, Kolkata, India.

${ }^{4}$ Professor \& Head, Dept of Anatomy, Medical College, Kolkata, India.

\section{ABSTRACT}

Background: A good understanding of morphometric measurements of the proximal femur is essential in order to decrease the risk of complications associated with orthopedic surgeries performed in the proximal femur due to traumatic injury, metabolic or vascular causes, and to achieve proper alignment of prosthesis to be implanted. The purpose of this study is to evaluate morphometry of neck of femur in Eastern Indian population.

Materials and Methods: The study was conducted on 50 dry adult femora [30 Right(R) and 20 Left(L)] available in the department of Anatomy of Medical College Kolkata, India.

Results: a) Mean and Standard Deviation (SD) of Vertical length of Head of femur was Right side: $38.56 \pm 2.50 \mathrm{~mm}$ and Left side: $38.07 \pm 3.43 \mathrm{~mm}$. b) Mean and SD of Width of neck of femur was Right side: $28.84 \pm 2.71 \mathrm{~mm}$ and Left side:28.09 $\pm 2.29 \mathrm{~mm}$. c) Mean and SD of length of Neck of femur on anterior aspect was Right side:26.37 $\pm 2.92 \mathrm{~mm}$ and Left side:26.12 $\pm 3.42 \mathrm{~mm}$. d) Mean and SD of length of Neck of femur on posterior aspect was Right side:31.65 $\pm 2.75 \mathrm{~mm}$ and Left side: $26.69 \pm 3.11 \mathrm{~mm}$. e) Neck-shaft angle on both sides were calculated.

Conclusion: Indian dimensions of proximal end of femur are different as compared to that of the values in other parts of the world. Present study will be useful for crafting suitable implants used for surgical correction of fracture neck femur in East Indian population.

KEYWORDS: Morphometry, Neck-shaft angle, Implant, Prosthesis, Width of neck, Vertical length of head of femur, Length of neck.

Corresponding Author: Dr. Gairik Sengupta, 15, Ramchandra Pally, Kolkata - 700008, India. Phone no: 9874621539, E-Mail: drgairiksengupta@yahoo.co.in

Access this Article online Quick Response code

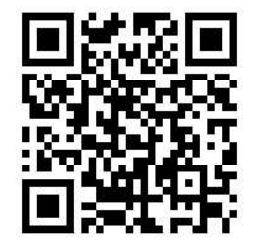

DOI: $10.16965 /$ ijar.2020.224

\begin{tabular}{|c|c|c|}
\hline \multicolumn{3}{|c|}{ Journal Information } \\
\hline \multicolumn{3}{|c|}{$\begin{array}{l}\text { International Journal of Anatomy and Research } \\
\text { ISSN (E) 2321-4287 | ISSN (P) 2321-8967 } \\
\text { https://www.ijmhr.org/ijar.htm } \\
\text { DOI-Prefix: https://dx.doi.org/10.16965/ijar }\end{array}$} \\
\hline \multicolumn{3}{|c|}{ Article Information } \\
\hline $\begin{array}{l}\text { Received: } 20 \text { Sep } 2020 \\
\text { Peer Review: } 20 \text { Sep } 2020 \\
\text { Revised: None }\end{array}$ & $\begin{array}{l}\text { Accepted: } 13 \text { Nov } \\
\text { Published }(0): 05 \\
\text { Published }(P): 05\end{array}$ & $\begin{array}{l}0 \\
2020 \\
2020\end{array}$ \\
\hline
\end{tabular}

\section{INTRODUCTION}

The femur is the longest and strongest bone in the human body [1]. It endures the mechanical load of whole body. We stand erect on our lower limbs. Body weight is transmitted from pelvis to head, neck and upper end of femur. So the resultant force is transmitted through the proximal end of femur. Here lies the importance of our study. The architecture of different parts of femur changes after child 
starts walking.

It is very difficult to identify sex by individual femur bones. Generally male femur bones are longer, thicker and heavier than female counterparts.

Different studies have shown that values of parameters for different races are different because of different diet, heredity, weather and other environmental factors [2]. In India malnutrition (mainly calcium and vitamin D3 deficiency) plays major role in fracture. Fracture neck femur is quite common in old age especially senile and menopausal osteoporosis. Increasing population of senior citizens is due to benefits of modern medicine. The implants used for surgical treatment of femoral fractures include dynamic hip screws, cancellous screws, blade and plates, different types of prosthesis like Austin Moor, Thompson's, Charnley's, Muller's prosthesis, unipolar and bipolar prosthesis etc [3].

In case of hip arthroplasty it is mandatory that the design and dimensions of femoral prosthesis should match with proximal femur. In case of ill-fitting prosthesis hip dislocation, implant fractures are common. But the implants available in the market are exclusively designed according to the western dimensions. The usage of these oversized implants adversely affects the functional end result of surgery [4].

Moreover not many studies are performed on morphometric analysis of proximal end of femur in Indian population. This study was thus carried out to define the morphometry of proximal end of femur in Eastern Indian population. This will help in modification of implant size for making prosthesis suitable for Eastern Indian population and in better choosing of prosthesis for better surgical outcome.

\section{MATERIALS AND METHODS}

The study was conducted on 50 dry adult femora from the anatomy department of Medical College Kolkata. Among the femurs 30 were of right side and 20 were of left side.

Exclusion Criteria: Grossly deformed bone, Fragmented or damaged bone, Bones with non prominent bony landmarks
Instruments used are as follows: Digital Vernier Caliper (accuracy $0.01 \mathrm{~mm}$ ), Goniometer (accuracy 1 degree), All the lengths were measured using digital vernier caliper and neckshaft angle was measured using goniometer.

\section{The following parameters were recorded:}

Vertical length of head of femur: It is the vertical diameter of the femoral head measuring the straight distance between the highest and lowest point of the head[2].(Fig.1)

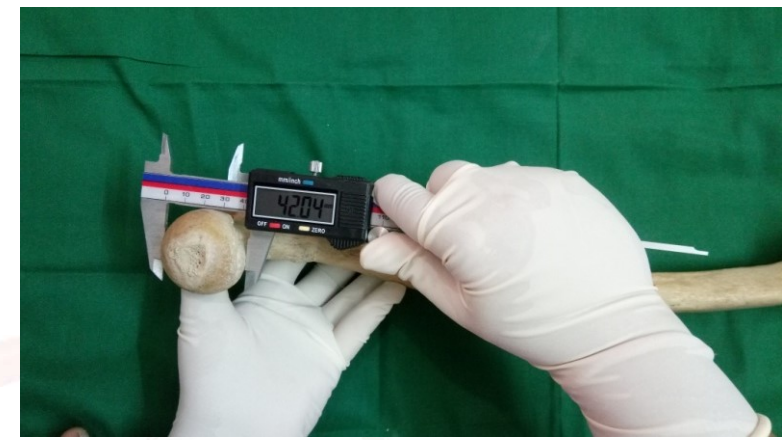

Fig.1: Image illustrating measurement of Vertical length of Head of femur.

Width of neck of femur: It is measured at the narrowest part of femoral neck in superoinferior direction[4].(Fig.2)

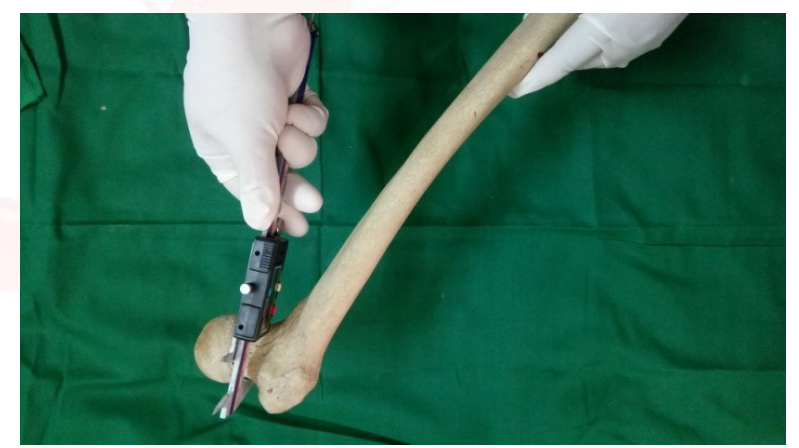

Fig.2: Image illustrating measurement of width of neck of femur.

Length of neck of femur on anterior aspect: It is the distance between the base of the head and inter-trochanteric line. It is measured along a line perpendicular to the inter-trochanteric crest[4].(Fig.3)

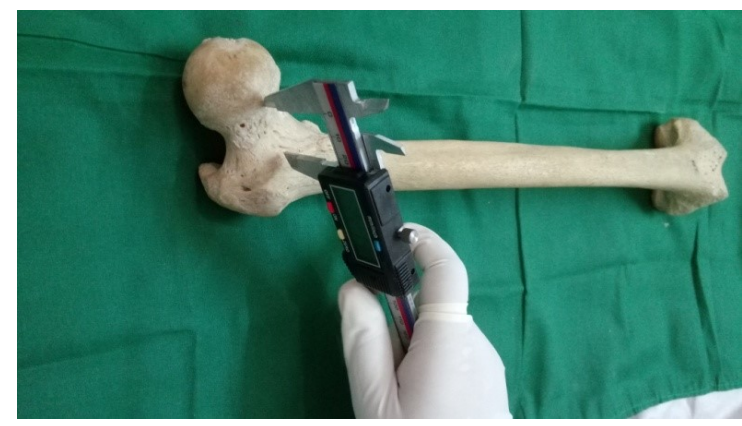

Fig. 3: Image illustrating measurement of length of neck of femur on anterior aspect. 
Length of neck of femur on posterior aspect: It is the distance between the base of the head and inter trochanteric crest. It is measured along a line perpendicular to the inter trochanteric crest[4].(Fig.4)

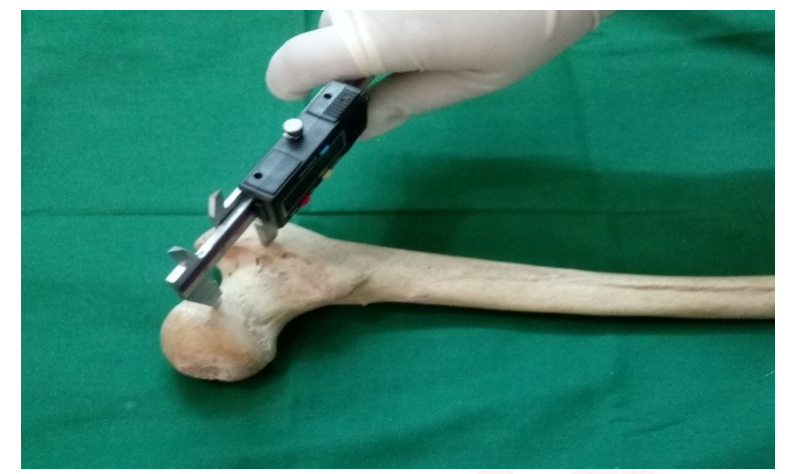

Fig.4: Image illustrating measurement of length of neck of femur on posterior aspect.

Neck-Shaft angle (NSA): It is the angle formed by neck axis and shaft axis of femur. This angle is also named as caput collum diaphysis(CCD) or cervico diaphysial angle[1][5].(Fig.5)

Neck axis: It is the line drawn from the centre of the femoral head to the centre of the femoral neck at it's narrowest part.

Shaft axis: It is the line drawn from the middle of the femoral condyles to the middle of the greater trochanter in two planes.

The mean NSA in adults ranges from $125^{\circ}$ to 140 ( on an average 135\%). The NSA is widest at birth and diminishes gradually until the age of 10 years (Birkenmaier et al 2010).

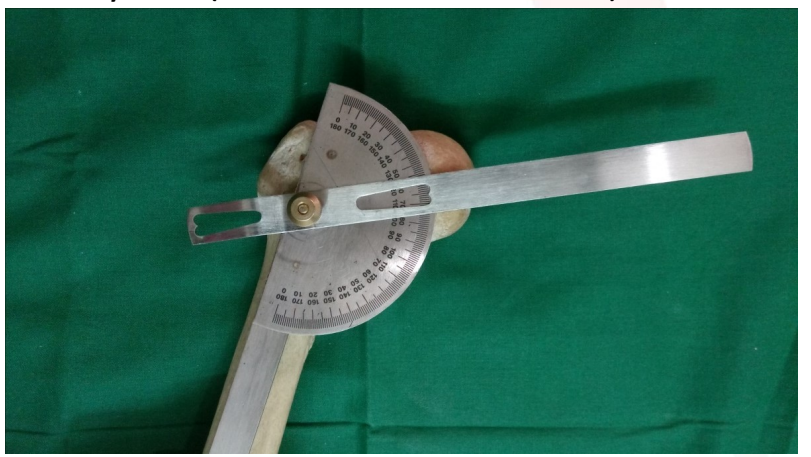

Fig.5: Image illustrating measurement of Neck-Shaft angle.

\section{RESULTS}

Vertical length of head of femur: The vertical length of head of femur on right side ranged from $33.03-42.72 \mathrm{~mm}$ with a mean of $38.56 \pm 2.50 \mathrm{~mm}$.

The vertical length of head of femur on left side ranged from $32.51-44.51 \mathrm{~mm}$ with a mean of $38.07 \pm 3.43 \mathrm{~mm}$.
Table 1: Vertical length of Head of femur.

\begin{tabular}{ccccccc}
\hline Side & $\begin{array}{c}\text { Number of } \\
\text { bones }\end{array}$ & $\begin{array}{c}\text { Minimum } \\
(\mathbf{m m})\end{array}$ & $\begin{array}{c}\text { Maximum } \\
(\mathbf{m m})\end{array}$ & $\begin{array}{c}\text { Mean } \\
(\mathbf{m m})\end{array}$ & $\begin{array}{c}\text { Standard } \\
\text { Deviation }\end{array}$ & p value \\
\hline Right & 30 & 33.03 & 42.72 & 38.56 & 2.5 & 0.56 \\
Left & 20 & 32.51 & 44.51 & 38.07 & 3.43 & \\
\hline
\end{tabular}

Width of Neck of femur: The mean width of neck of femur on right side was estimated to be $28.84 \pm 2.71 \mathrm{~mm}$ with a range between 22.16 $34.63 \mathrm{~mm}$.

The mean width of neck of femur on left side was estimated to be $28.09 \pm 2.29 \mathrm{~mm}$ with a range between $24.46-32.88 \mathrm{~mm}$.

Table 2: Width of Neck of femur.

\begin{tabular}{|c|c|c|c|c|c|c|}
\hline Side & $\begin{array}{c}\text { Number of } \\
\text { bones }\end{array}$ & $\begin{array}{c}\text { Minimum( } \\
\mathrm{mm})\end{array}$ & $\begin{array}{l}\text { Maximum } \\
(\mathrm{mm})\end{array}$ & $\begin{array}{l}\text { Mean } \\
(\mathrm{mm})\end{array}$ & $\begin{array}{l}\text { Standard } \\
\text { Deviation }\end{array}$ & $p$ value \\
\hline Right & 30 & 22.16 & 34.63 & 28.84 & 2.71 & \multirow{2}{*}{0.314} \\
\hline Left & 20 & 24.46 & 32.88 & 28.09 & 2.29 & \\
\hline
\end{tabular}

Length of neck of femur on anterior aspect: The mean length of neck of femur on anterior aspect on right side was estimated to be $26.37 \pm 2.92 \mathrm{~mm}$ with a range between 20.55 $31.02 \mathrm{~mm}$.

The mean length of neck of femur on anterior aspect on left side was estimated to be $26.12 \pm 3.42 \mathrm{~mm}$ with a range between 20.35 $32.88 \mathrm{~mm}$.

Table 3: Length of Neck of femur on anterior aspect.

\begin{tabular}{ccccccc}
\hline \multirow{2}{*}{ Side } & $\begin{array}{c}\text { Number of } \\
\text { bones }\end{array}$ & $\begin{array}{c}\text { Minimum } \\
(\mathrm{mm})\end{array}$ & $\begin{array}{c}\text { Maximum } \\
(\mathrm{mm})\end{array}$ & $\begin{array}{c}\text { Mean } \\
(\mathrm{mm})\end{array}$ & $\begin{array}{c}\text { Standard } \\
\text { Deviation }\end{array}$ & p value \\
\hline Right & 30 & 20.55 & 31.02 & 26.37 & 2.92 & 0.783 \\
Left & 20 & 20.35 & 32.88 & 26.12 & 3.42 & \\
\hline
\end{tabular}

Length of neck of femur on posterior aspect: The mean length of neck of femur on posterior aspect on right side was estimated to be $31.65 \pm 2.75 \mathrm{~mm}$ with a range between 25.99-37.84mm.

The mean length of neck of femur on posterior aspect on left side was estimated to be $29.69 \pm 3.11 \mathrm{~mm}$ with a range between 23.97 $35.98 \mathrm{~mm}$.

Table 4: Length of Neck of femur on posterior aspect.

\begin{tabular}{ccccccc}
\hline Side & $\begin{array}{c}\text { Number of } \\
\text { bones }\end{array}$ & $\begin{array}{c}\text { Minimum } \\
(\mathrm{mm})\end{array}$ & $\begin{array}{c}\text { Maximum } \\
(\mathrm{mm})\end{array}$ & $\begin{array}{c}\text { Mean } \\
(\mathrm{mm})\end{array}$ & $\begin{array}{c}\text { Standard } \\
\text { Deviation }\end{array}$ & p value \\
\hline Right & 30 & 25.99 & 37.84 & 31.65 & 2.75 & 0.269 \\
Left & 20 & 23.97 & 35.98 & 29.69 & 3.11 & \\
\hline
\end{tabular}

Neck-Shaft angle (NSA): The NSA of femur on right side ranged from $115^{\circ}-138^{\circ}$ with a mean of $124.53 \pm 6.35$ ․

The NSA of femur on right side ranged from $110^{\circ}-140$ 은 with a mean of $126.9 \pm 7.67 \%$. 
Table 5: Neck-Shaft Angle.

\begin{tabular}{ccccccc}
\hline Side & $\begin{array}{c}\text { Number of } \\
\text { bones }\end{array}$ & $\begin{array}{c}\text { Minimum } \\
\text { (degrees) }\end{array}$ & $\begin{array}{c}\text { Maximum } \\
\text { (degrees) }\end{array}$ & $\begin{array}{c}\text { Mean } \\
\text { (degrees) }\end{array}$ & $\begin{array}{c}\text { Standard } \\
\text { Deviation }\end{array}$ & p value \\
\hline Right & 30 & 115 & 138 & 124.53 & 6.35 & 0.24 \\
Left & 20 & 110 & 141 & 126.9 & 7.67 & \\
\hline
\end{tabular}

Data recorded in the morphometric measurements of the proximal femur does not show any significant difference between mean values of either side $(p>0.05$, when compared by student's t test; variables normally distributed as shown by Shapiro-Wilk test). Difference between such measurements in our study and that obtained in other studies are given below.

\section{DISCUSSION}

Previously many studies were performed regarding the various parameters of femur using different materials like dry bones, cadaveric specimens, plain radiographs, Computed Tomography (CT) scans and Magnetic Resonance Imaging(MRI) scans. Several quantitative anatomical studies of adult femora belonging to different races, culture and ethnic group have been carried out in different countries.

Vertical length of head of femur: The values of vertical length of head of femur in present study was less than that in most of the previous studies.

Table 6: Comparison of Vertical length of Head of femur with previous studies.

\begin{tabular}{|c|c|c|c|c|c|c|c|}
\hline Study & Year & Country & $\begin{array}{l}\text { Material for } \\
\text { study }\end{array}$ & $\begin{array}{c}\text { Sample size } \\
\text { (n) }\end{array}$ & $\begin{array}{c}\text { Mean (in } \\
\mathrm{mm} \text { ) }\end{array}$ & S.D. & P value \\
\hline \multirow{2}{*}{ Taner Ziylan et al[6] } & \multirow{2}{*}{2002} & \multirow{2}{*}{ Turkey } & \multirow{2}{*}{ Dry bones } & $36(R)$ & $45.2(\mathrm{R})$ & $4.0(\mathrm{R})$ & \multirow{6}{*}{$\begin{array}{l}<0.005(R) \\
<0.005(L)\end{array}$} \\
\hline & & & & $36(L)$ & $43.4(L)$ & $3.2(L)$ & \\
\hline \multirow{2}{*}{ Anuj et al[4] } & \multirow{2}{*}{2013} & \multirow{2}{*}{ India } & \multirow{2}{*}{ Dry bones } & $42(R)$ & $45.21(\mathrm{R})$ & $1.87(\mathrm{R})$ & \\
\hline & & & & $42(L)$ & $46.18(L)$ & $1.88(\mathrm{~L})$ & \\
\hline \multirow{2}{*}{ Present study } & \multirow{2}{*}{2018} & \multirow{2}{*}{ India } & \multirow{2}{*}{ Dry bones } & $30(R)$ & $38.56(R)$ & $2.5(\mathrm{R})$ & \\
\hline & & & & $20(L)$ & $38.07(L)$ & $3.43(L)$ & \\
\hline
\end{tabular}

Significant difference $(p<0.05)$ present as obtained by ANOVA test between the groups.

Width of Neck of femur: The value of width of neck of femur in present study was less than that in most of the previous studies. However the observations were comparable with the studies done by Muley Mrunal et al [6] and Baharuddin MY et al [7].

Significant difference $(p<0.05)$ present as obtained by ANOVA test between the groups Length of neck of femur on anterior aspect: The length of neck of femur on anterior aspect in present study was less than all the previous studies.

Table 7: Comparison of Width of neck of femur with previous studies.

\begin{tabular}{|c|c|c|c|c|c|c|c|}
\hline Study & Year & Country & $\begin{array}{l}\text { Material } \\
\text { for study }\end{array}$ & $\begin{array}{l}\text { Sample } \\
\text { size(n) }\end{array}$ & $\begin{array}{c}\text { Mean(in } \\
\mathrm{mm})\end{array}$ & S.D. & $p$ value \\
\hline \multirow{2}{*}{ Taner Ziylan et al[8] } & \multirow{2}{*}{2002} & \multirow{2}{*}{ Turkey } & \multirow{2}{*}{ Dry bones } & $36(R)$ & $30.70(R)$ & $3.6(\mathrm{R})$ & \multirow{8}{*}{$\begin{array}{l}<0.005(R) \\
<0.005(L)\end{array}$} \\
\hline & & & & $36(L)$ & $30.60(L)$ & $3.0(L)$ & \\
\hline \multirow{2}{*}{ Edurardo Branco et al[9] } & \multirow{2}{*}{2010} & \multirow{2}{*}{ Brazil } & Radiograph & $41(\mathrm{R})$ & $30.96(R)$ & $2.7(R)$ & \\
\hline & & & s & $68(L)$ & $31.00(L)$ & $3.0(L)$ & \\
\hline \multirow{2}{*}{ Muley Mrunal et al[[6] } & \multirow{2}{*}{2017} & \multirow{2}{*}{ India } & \multirow{2}{*}{ Dry bones } & $78(\mathrm{R})$ & $29.38(R)$ & $2.5(\mathrm{R})$ & \\
\hline & & & & $72(L)$ & $28.86(L)$ & $3.47(L)$ & \\
\hline \multirow{2}{*}{ Present study } & \multirow{2}{*}{2018} & \multirow{2}{*}{ India } & \multirow{2}{*}{ Dry bones } & $30(R)$ & $28.09(R)$ & $2.71(\mathrm{R})$ & \\
\hline & & & & $20(L)$ & $28.84(L)$ & $2.29(L)$ & \\
\hline
\end{tabular}

Significant difference $(p<0.05)$ present as obtained by ANOVA test between the groups Length of neck of femur on anterior aspect: The length of neck of femur on anterior aspect in present study was less than all the previous studies.

Table 8: Comparison of Length of Neck of femur on anterior aspect with other studies.

\begin{tabular}{|c|c|c|c|c|c|c|c|}
\hline Study & Year & Country & $\begin{array}{c}\text { Material for } \\
\text { study }\end{array}$ & $\begin{array}{c}\text { Sample } \\
\text { size(n) }\end{array}$ & $\begin{array}{l}\text { Mean } \\
\text { (in } \mathrm{mm} \text { ) }\end{array}$ & S.D. & $p$ value \\
\hline \multirow{2}{*}{ Edurardo Brancho et al[9] } & \multirow{2}{*}{2010} & \multirow{2}{*}{ Brazil } & \multirow{2}{*}{ Radiographs } & $41(\mathrm{R})$ & $30.10(\mathrm{R})$ & $4.3(\mathrm{R})$ & \multirow{8}{*}{$\begin{array}{l}<0.005(\mathrm{R}) \\
<0.005(\mathrm{~L})\end{array}$} \\
\hline & & & & $68(L)$ & $30.50(L)$ & $4.1(L)$ & \\
\hline \multirow{2}{*}{ Osorio H et al[10] } & \multirow{2}{*}{2012} & \multirow{2}{*}{ Chile } & \multirow{2}{*}{ Dry bones } & $44(\mathrm{R})$ & $35.9(\mathrm{R})$ & $4.1(\mathrm{R})$ & \\
\hline & & & & 37 (L) & $36.4(L)$ & $4.4(L)$ & \\
\hline \multirow{2}{*}{ Muley Mrunal et al[6] } & \multirow{2}{*}{2017} & \multirow{2}{*}{ India } & \multirow{2}{*}{ Dry bones } & $78(\mathrm{R})$ & $34.96(\mathrm{R})$ & $7.18(\mathrm{R})$ & \\
\hline & & & & 72 (L) & $33.42(L)$ & $4.12(L)$ & \\
\hline \multirow{2}{*}{ Present study } & \multirow{2}{*}{2018} & \multirow{2}{*}{ India } & \multirow{2}{*}{ Dry bones } & $30(\mathrm{R})$ & $26.12(R)$ & $2.92(\mathrm{R})$ & \\
\hline & & & & $20(L)$ & $26.37(L)$ & $3.42(L)$ & \\
\hline
\end{tabular}

Significant difference $(p<0.05)$ present as obtained by ANOVA test between the groups

Length of neck of femur on posterior aspect: The length of neck of femur on posterior aspect in present study was less than values of the previous studies.

Table 9: Comparison of Length of Neck of femur on posterior aspect with other studies.

\begin{tabular}{|c|c|c|c|c|c|c|c|}
\hline Study & Year & Country & $\begin{array}{l}\text { Material } \\
\text { for study }\end{array}$ & $\begin{array}{l}\text { Sample } \\
\text { size(n) }\end{array}$ & $\begin{array}{c}\text { Mean (in } \\
\mathrm{mm} \text { ) }\end{array}$ & S.D. & $p$ value \\
\hline $\begin{array}{c}\text { Muley Mrunal et } \\
\text { al[6] }\end{array}$ & 2017 & India & Dry bones & $78(\mathrm{R}) 72(\mathrm{~L})$ & $\begin{array}{l}39.55(\mathrm{R}) \\
40.00(\mathrm{~L})\end{array}$ & $\begin{array}{c}5.81(\mathrm{R}) \\
4.6(\mathrm{~L})\end{array}$ & \multirow{2}{*}{$\begin{array}{l}<0.05(R) \\
<0.05(L)\end{array}$} \\
\hline Present study & 2018 & India & Dry bones & $30(R) 20(L)$ & $\begin{array}{l}31.65(R) \\
29.69(L)\end{array}$ & $\begin{array}{l}2.75(\mathrm{R}) \\
3.11(\mathrm{~L})\end{array}$ & \\
\hline
\end{tabular}

Significant difference $(p<0.05)$ present as obtained by Student's test between the groups

Neck-Shaft angle (NSA): The NSA of femur is widely variable between the populations of the two hemispheres. The value of NSA in present study was slightly more than that observed by PF Umbese [8] and Amith $R$ et al [9] and less than PA Toogood [10] and HD Atkinson and in line with the study by Liang $\mathrm{J}$. 
Table 10: Comparison of NSA of femur with previous studies.

\begin{tabular}{|c|c|c|c|c|}
\hline Study & Year & Country & Material for study & $\begin{array}{c}\text { Mean NSA } \\
\text { (in degrees) }\end{array}$ \\
\hline M Lequesne & 2004 & France & X-ray & 132.8 \\
\hline PF Umebese[11] & 2005 & Nigeria & X-ray & 121 \\
\hline PA Toogood[12] & 2008 & America & $\begin{array}{c}\text { Dry bones-Digital } \\
\text { photo }\end{array}$ & 129.2 \\
\hline HD Atkinson[13] & 2010 & England & CT & $\begin{array}{c}\text { Male-129 } \\
\text { Female-128 }\end{array}$ \\
\hline Amith R et al[14] & 2016 & India & $\begin{array}{c}\text { Dry bones- } \\
\text { Computer assisted }\end{array}$ & 121.2 \\
\hline Present study & 2018 & India & Dry bones & $\begin{array}{c}\text { Right-124.53 } \\
\text { Left-126.9 }\end{array}$ \\
\hline
\end{tabular}

Significant difference, if any with the abovementioned studies could not be determined due to lack of available data of mean and standard deviation in all of these studies.

\section{CONCLUSION}

In today's era, where the average life expectancy is ever increasing, we are also faced with the responsibility of caring for an increasing proportion of the elderly. And as we all know, maintaining the mobility of such a person can improve both their physical \& mental wellbeing, as desired once by the WHO definition of HEALTH.

The present study is aimed at adding to our existing knowledge of the morphometry of proximal end of femur and their variations across different populations, which may be relevant for:

1. Diagnosis of congenital \& acquired pathologies of hip joint.

\section{Designing prosthesis for hip replacement}

3. Decreasing the risk of complications by allowing prognosis to be judged by the morphometry \& biomechanics of the pelvic girdle \& allowing proper and early rehabilitation.

Our study observed a significant difference existing between the morphometric measurements obtained in other studies in India and also in different parts of the world. Therefore, further studies with larger sample sizes belonging to different ethnic groups, races, cultures are required to minimize error in clinical decision making and interventions.

\section{ABBREVIATIONS}

R - Right, L - left,

NSA - Neck shaft angle, SD - Standard deviation

\section{ACKNOWLEDGEMENTS}

Department of Anatomy, Medical College, Kolkata, India.

\section{Conflicts of Interests: None}

\section{REFERENCES}

[1]. Sandring S, Tubbs RS. Pelvic girdle, gluteal region and thigh. Gray's Anatomy:The Anatomical Basis of Clinical Practice.41st ed. Edinburgh: Elsevier Churchill Livingstone;2016;1348-1359 \& 1379

[2]. Joshi V R,Nair K S,Thaduri N,Gupta S D. Morphometric study of proximal end of femur in central Indian population. Int J Med Sci \& Clinical Inventions 2017;4(2):2679-2681

https://doi.org/10.18535/ijmsci/v4i2.07

[3]. Maheswari J, Annexure I, Orthopaedic instruments and implants. Essential Orthopaedics. 4th ed;2011.

[4]. Muley M, Bhuiyan P. Morphometric study of neck of dry adult femora. Int J Anat Res 2017; 5(3.2):4317-4320.

https://doi.org/10.16965/ijar.2017.321

[5]. Reikeras O, Hoiseth A. and Reigstad A, Fonstelien E. Femoral neck angles. Acta orthop. Scand. 1982;53:775-79.

https://doi.org/10.3109/17453678208992291 PMid:7136588

[6]. Muley M, Bhuiyan P. Morphometric study of neck of dry adult femora. Int J Anat Res 2017; 5(3.2):43174320 https://doi.org/10.16965/ijar.2017.321

[7]. Baharuddin A M Y, Kadir R A,Zulkifly A H,Saat A,Aziz A A \& Lee M. Morphometric study of the proximal femur in Malay population. Int. J. Morphol. , 2011;29(4):1321-1325

https://doi.org/10.4067/S0717-95022011000400042

[8]. Taner Z,Khali A M.An Analysis of Anatolian Human Femur Anthropometry.Turk J Med Sci. 2002;32:231-235.

[9]. De Sousa EB, Fernades RMP, Mathias MB, Rodrigues MR, Ambram AJ, Babinski MA. Morphometric study of the proximal femur. Int. J. Morphol.,2010;28(3):835-840.

https://doi.org/10.4067/S0717-95022010000300027

[10]. Osorio H; Schorwer K.; Coronado C; Delgado J, \& Aravena P. Proximal femoral epiphysis anatomy in Chilean population. Orthopedic and forensic aspects. Int. J. Morphol. 2012;30(1):258-262

https://doi.org/10.4067/S0717-95022012000100046

[11]. Umebese PF, Adeyekun A, Moin M. Radiological assessment of femoral neck-shaft \& anteversion angles in adult Nigerian HIPS. Niger Postgrad Med J. 2005 Jun;12(2):106-9

[12]. Toogood PA, Skalak A, Cooperman DR. Proximal Femoral Anatomy in the Normal Human Population. Clin Orthop Relat Res. 2009;467:876-85 https://doi.org/10.1007/s11999-008-0473-3 PMid:18758876 PMCid:PMC2650061 
[13]. Atkinson, H.D., Johal, K.S., Willis-Owen, C. et al. Differences in hip morphology between the sexes in patients undergoing hip resurfacing. J Orthop Surg Res 5, 76 (2010). https://doi.org/10.1186/1749799X-5-76 PMid:20950444 PMCid:PMC2972264

[14]. Amith R, Beena N, Vinay KV. Morphometry of femoral neck shaft angle in dry femora of south India by computer assisted image analysis method. Int J Anat Res 2017;5(2.1):3753-3758

https://doi.org/10.16965/ijar.2017.167

How to cite this article:

Ishita Sengupta (Ghosh), Madhumita Mahato, Gairik Sengupta, Jadab Chandra Chattopadhyay . A MORPHOMETRIC STUDY OF THE PROXIMAL END OF DRY ADULT FEMORA. Int J Anat Res 2020;8(4.2):7799-7804. DOI: 10.16965/ijar.2020.224 